\title{
STRATEGI PENGAWASAN KEIMIGRASIAN SERTA PERAN HUKUM KEIMIGRASIAN DALAM MENGHADAPI ANCAMAN KEDAULATAN NEGARA DI INDONESIA
}

\section{(ROLE OF IMMIGRATION AND LEGAL STRATEGY EFFORTS IMMIGRATION IN FACING THREATS OF THE STATE SOURCE IN INDONESIA)}

\author{
Dinda Mayang ${ }^{(1)}$, Panca Wani ${ }^{(2)}$,Warisul Ambia ${ }^{(3)}$ \\ 1,2,3Politeknik Imigrasi Badan Pengembangan Sumber Daya Manusia Hukum dan HAM RI. Indonesia \\ Email : dindamayang@gmail.com ${ }^{(1)}$, pancasimamora@gmail.com ${ }^{(2)}$,warisulambia999@gmail.com ${ }^{()}$
}

\begin{abstract}
ABSTRAK
Keimigrasian merupakan hal ihwal lalu lintas orang yang masuk atau keluar wilayah Indonesia serta pengawasannya dalam rangka menjaga tegaknya kedaulatan negara (UU No 6 Tahun 2011 pasal satu angka 1). Saat ini Total jumlah penduduk dunia tahun 2019 adalah sebanyak 7.714.576.923 dan terus bertambah tentunya. Bertumbuh 1.07 persen dibanding tahun 2018 atau bertambah 81.757.598 penduduk. Adapun jumlah usia rata-rata penduduk dunia menurut worldometers adalah 29,9 tahun. Ini merupakan suatu kondisi dimana siklus kepadatan dan lalu lintas orang di dunia semakin berkembang dan meningkat. Jumlah penduduk terbanyak masih didominasi Cina. Negara Tirai Bambu ini mencatatkan 1.417.930.226 jiwa penduduk. Total penduduk Cina lima kali lebih banyak dibandingkan jumlah penduduk Indonesia. Di peringkat dua, penduduk paling banyak di dunia ditempati oleh India. Penduduk India berjumlah 1.362.483.286 sejak artikel ini dibuat dan terus bertambah. India mengejar Cina yang hanya berjarak sekitar 50 juta penduduk. Indonesia merupakan negara peringkat ke 4 dengan jumlah penduduk terbanyak ke 4 di dunia dengan jumlah penduduk mencapai 257.912 .349 jika di persenkan mencapai $3.44 \%$ penduduk bumi. Dengan adanya perkembangan globalisasi dan ekonomi yang kian meningkat dan jumlah peningkatan penduduk yang kian bertambah membuat manusia bermigrasi ke negara- negara lain. Dengan adanya dampak perubahan siklus perekonomian di setiap negara berbeda beda serta mobilitas sosial dan diferensiasi sosial juga ketimpangan sosial maka akan timbul kriminalitas di setiap negara. Kriminalitas bukan hanya dari segi ekonomi saja tetapi, bisa dari segi politik, sosial, serta berdampak juga terhadap keamanan negara. Dengan adanya hal tersebut, maka keimigrasian harus selektif dalam menerima orang asing (foreign) ke Indonesia, guna menjaga stabilitas keamanan negara dari ancaman, gangguan, dan hambatan dari luar.
\end{abstract}

Kata Kunci: Penegakan Hukum, Orang Asing , Keimigrasian, Kejahatan

\section{ABSTRACT}

Immigration is a matter of the traffic of people entering or leaving the territory of Indonesia and its supervision to maintain the upholding of state sovereignty (Law No. 6 of 2011 article one point 1). Currently, the total world population in 2019 is 7,714,576,923 and continues to grow, of course. Growth of 1.07 percent compared to 2018 or an increase of 81,757,598 inhabitants. The total age of the world's population according to world meters is 29.9 years. This is a condition where the cycle of density and traffic of people in the world is growing and increasing. The largest population 
is still dominated by China. The Bamboo Curtain country has recorded 1,417,930,226 inhabitants. The total population of China is five times more than the total population of Indonesia. In the second place, India has the largest population in the world. The population of India has numbered $1,362,483,286$ since this article and is counting. India is catching up with China which is only about 50 million inhabitants. Indonesia is the 4th country with the 4th largest population in the world with a population reaching $257,912,349$ if it reaches $3.44 \%$ of the earth's population. With the development of globalization and the increasing economy and the increasing number of population, people migrate to other countries. The impact of changes in the economic cycle in each country is different and social mobility and social differentiation as well as social inequality will result in crime in each country. Crime is not only from an economic point of view but, from a political, social point of view, and also has an impact on state security. With this, immigration must be selective in accepting foreigners (foreign) to Indonesia, to maintain the stability of the country's security from threats, disturbances, and obstacles from outside.

Key Words: Law Enforcement, Foreigners, Immigration, Crime

\section{PENDAHULUAN}

\section{Latar Belakang}

Permasalahan imigrasi di Indonesia semakin lama semakin meningkat, dan tingkat kesukaran nya juga semakin bertambah. Imigrasi sangat berperan penting terhadap kedaulatan negara yang dimana Imigrasi merupakan pintu gerbang utama negara. Imigrasi sangat berperan penting terhadap integrasi negara dalam mencegah ancaman dan hambatan bagi pembangunan negara. Ancaman terbagi ke dalam dua macam, ancaman kedaulatan negara yang berasal dari faktor eksternal dan ancaman kedaulatan negara yang berasal dari faktor internal. Ancaman yang berasal dari faktor luar yakni pengaruh Ideologi dari negara lain yang berdampak buruk terhadap ketahanan negara, kemudian dari segi sosial bisa berupa pengaruh budaya yang bersifat chauvinisme dan ketidaksetaraan sosial atau ada diferensiasi sosial yang sangat mencolok yang tidak sesuai dengan Ideologi Pancasila. Kemudian adanya kejahatan yang bersifat Internasional dan universal.

Kejahatan Internasional tidak lepas juga dengan pengawasan keimigrasian. Pengawasan keimigrasian sangat berperan penting dalam menjaga keamanan, pengamanan negara dari gangguan yang bersifat eksternal maupun internal. Orang asing harus mentaati apa saja yang di atur dalam Kebijakan selektif keimigrasian serta tunduk pada aturan hukum di Indonesia.Fenomena kejahatan transnasional terorganisir (Transnational Organized Crime) ( TOC) terus mengemuka dan membutuhkan perhatian serius dari setiap negara. Bentukbentuk TOC - seperti; penyelundupan manusia (Human Trafficing), aksi-aksi pembajakan, kejahatan internet (Cyber Crime), terorisme, peredaran narkoba (Drug Trafficking), pencucian uang (Money Loundering), penyelundupan senjata, dan aneka kejahatan ekonomi internasional semakin berkembang pesat dan telah teridentifikasi sebagai ancaman keamanan baru dan masyarakat, negara. Demikian pula fenomena yang terjadi di Indonesia, kejahatan transnasional membutuhkan pehatian bagi pemerintah dan masyarakat untuk mengatasinya. Sehingga, kejahatan trasnasional dapat dicegah. Kemudian ada ancaman yang berasal dari faktor Internal yang berupa provokasi terhadap kerusuhan yang tidak menerima kebijakan dari pemerintah, yang mengakibatkan daerah tersebut ingin memisahkan diri dari Negaranya.

\section{Rumusan Masalah}

Berdasarkan uraian di atas, maka rumusan masalah yang dibahas dalam peneltian ini adalah sebagai berikut:

1. Apa saja pemahaman keimigrasian dalam menghadapi permasalahan kedaulatan negara? 
2. Apa saja hubungan antara keimigrasian dengan integrasi dan kedaulatan negara dan apa saja dasar hukum antara kedua tersebut?

3. Bagaimana peran dan strategi pengawasan keimigrasian dalam menghadapi ancaman baik faktor eksternal maupun faktor internal terhadap pertahanan kedaulatan negara?

\section{Tujuan}

Adapun tujuan dari pembuatan jurnal ini adalah sejauh apa peran pemerintah bersama dengan keimigrasian dalam menghadapi ancaman, dan hambatan bagi kedaulatan negaraserta menghindari ancaman yang bersifat membahayakan bagi masyarakat. Dan selalu meningkatkan pengawasan keimigrasian serta harus selektif dalam menerima orang asing ke Indonesia. Serta memahami seberapa banyak persentase ancaman yang bersifat eksternal maupun internal dengan keimigrasian.

\section{Metode Penelitian \\ Pendekatan}

Dengan memahami pendalaman ilmu yang bersifat historis (sejarah) seperti sejarah kedaulatan negara dan ancaman kedualatan negara serta dampaknya terhadap keamanan negara di Indonesia, dari segi empiris yaitu berdasarkan hasil pengamatan dan pembahasan dari berbagai aktivitas kehidupan manusia.

\section{Metode Pengumpulan Data}

Metode pengumpulan data nya bersifat empiris, normatif dan berdasarkan historis

\section{Teknik Analisa Data}

1. Menggunakan Teknik secara deskriptif dalam menampilkan kajian data terkait ancaman kedaulatan negara. Menggunakan teknik secara Empiris terhadap pemahaman dan kejadian berdasarkan lapangan dan fakta pada kejahatan yang berupa ancaman negara terhadap pengawasan keimigrasian.

\section{PEMBAHASAN}

Keimigrasian merupakan satu tonggak dan pilar awal dalam menghadapi ancaman yang dapat mengganggu kedaulatan negara yang berasal dari faktor luar. Secara yuridis Keimigrasian menurut Pasal 1 Angka (1) Undang- Undang Nomor 6 Tahun 2011 tentang) menjelaskan pemahamannya sebagai berikut:"Keimigrasian adalah hal ihwal lalu lintas orang yang masuk atau keluar Wilayah Indonesia serta pengawasannya dalam rangka menjaga tegaknya kedaulatan negara”. Kemudian peran fungsi terhadap imigrasi terdapat pada Pasal 1Angka (3) disebutkan Fungsi Imigrasi, yaitu: (1) pelayanan masyarakat, penegakan hukum, (3) keamanan negara, (4) pembangunan kesejahteraan masyarakat, maka Imigrasi memiliki peran penting dalam menjaga kedaulatan negara.

\begin{tabular}{lrr}
\multicolumn{3}{c}{ Kedaulatan Negara adalah kekuasaan } \\
mutlak atau kekuasaaan & tertinggi \\
atas penduduk dan wilayah bumi & beserta \\
isinya yang dipunyai & oleh
\end{tabular}
suatu sistem negara nasional yang berdaulat. Kedaulatan Negara dalam Arti kenegaraan adalah kekuasaan penuh dan tertinggi dalam suatu negara untuk mengatur seluruh wilayahnya tanpa campur tangan dari pemerintah negaralain. Dengan kata lain perspektif keimigrasian dan kedaulatan negara merupakan hubungan yang sangat erat terhadap keamanan negara, Menurut Kusumaatmadja Kedaulatan negara merupakan suatu sifat atau ciri hakiki dari suatu negara, dimana negara tersebut berdaulat, tetapi mempunyai batas-batasnya yaitu ruang berlakunya kekuasaan tertinggi ini dibatasi oleh batas- batas wilayah negara itu, diluar wilayahnya negara tersebut tidak lagi memiliki kekuasaan demikian ( Kusumaatmadja, 1982). Dengan menjaga ancaman dari luar yang dapat mengancam kedaulatan negara maka dibentuk adanya 
pengawasan keimigrasian. Maksud dari pengawasan keimigrasian adalah Pengawasan Keimigrasian adalah serangkaian kegiatan yang dilakukan untuk mengumpulkan, mengolah, serta menyajikan data dan informasi keimigrasian warga negara Indonesia dan orang asing dalam rangka memastikan dipatuhinya ketentuan peraturan perundang-undangan di bidang Keimigrasian. Hubungan antara keimigrasian dengan kedaulatan negara terletak pada TPI, TPI merupakan cerminan kedaulatan negara imajiner yang ditentukan oleh Otoritas Imigrasi, Keberadaan TPI berkaitan erat dengan Area Imigrasi. Pasal 22 ayat (2) UU No. 6 Tahun 2011 menentukan bahwa Area imigrasi merupakan area terbatas yang hanya dapat dilalui oleh penumpang atau awak alat angkut yang akan keluar atau masuk Wilayah Indonesia atau pejabat dan petugas yang berwenang. Kedaulatan disini dimaksud bahwa bahwa imigrasi merupakan otoritas dan peran penting terhadap keluar masuknya seseorang baik WNA maupun WNI (Syahrin, M. A. 2018)

Berdasarkan kebijakan selektif (selective policy) yang menjunjung tinggi nilai hak asasi manusia, diatur masuknya orang asing kedalam wilayah Indonesia, demikian pula bagi orang asing yang memperoleh Izin Tinggai di wilayah Indonesia harus sesuai dengan maksud dan tujuannya berada di Indonesia. Berdasarkan kebijakan dimaksud serta dalam rangka melindungi kepentingan nasional, hanya orang asing yang memberikan manfaat serta tidak membahayakan keamanan dan ketertiban umum diperbolehkan masuk dan berada di wilayah Indonesia. Pada prinsipnya, kebijakan selektif ini mengharuskan bahwa:

1. hanya orang asing yang bermanfaat yang diperbolehkan masuk dan berada di wilayah Indonesia;

2. hanya orang asing yang tidak membahayakan keamanan dan ketertiban umum yang diperbolehkan masuk dan berada di wilayah Indonesia;

3. orang asing harus tunduk pada peraturan hukum di Indonesia;

4. orang asing yang masuk dan berada di wilayah Indonesia harus sesuai dengan maksud dan tujuannya.

Berdasarkan prinsip ini, maka hanya orang asing yang dapat memberikan manfaat bagi kesejahteraan rakyat, bangsa, dannegara, wilayah Indonesia. Bahkan dalam tafsir lain, pergerakan orang asing tersebut harus dapat sesuai dengan ideologi negara dan tidak mengancam keutuhan bangsa. Sehingga dasar dari hubungan keimigrasian dengan kedaulatan negara berawal dari kebijakan selektif keimigrasian yang terdapat pada poin ke dua yang dimana tidak membahayakan kedaulatan negara dan keamanan negara.

\section{Relasi antara Keimigrasian dengan Kedaulatan negara}

Imigrasi berfungsi sebagai penjaga pintu gerbang negara, dapat dikatakan demikian karena imigrasi merupakan institusi pertama dan terakhir yang menyaring kedatangannya dan keberangkatan orang asing ke dan dari wilayah Republik Indonesia, pelaksanaan fungsi keamanan yang ditujukan kepada Warga Negara Indonesia dijabarkan melalui tindakan pencegahan ke luar negeri bagi Warga Negara Indonesia atas permintaan Menteri Keuangan dan Kejaksaan Agung tindakan ini guna untuk menghindari adanya ancaman dan gangguan yang dapat menyebabkan hilangnya kotrol kedaulatan negara khusus Warga Negara Indonesia (WNI) tidak dapat dilakukan pencegahan karena alasan-alasan keimigrasian belaka.Dalam sejarah antar bangsa, dan praktik kenegaraan, keterkaitan antara kedaulatan (sovereignty) dan hak menentukan nasib sendiri suatu bangsa (national self-determination) seringkali menjadi sumber ketegangan dan bahkan 
konflik dengan kekerasan di berbagai wilayah negara ( Riyanto, S. 2012). ini juga terjadi proses interdependensi legal antara sistem hukum domestik dengan sistem hukum multilateral yang dibangun dan diterima oleh masyarakat negara-negara pada aras regional maupun internasional. Ini menjadi alasan mengapa kedaulatan negara menjadi peran penting terhadap pembangunan bangsa( Riyanto, S. 2012). Berbicara tentang ancaman kedaulatan negara yang berasal dari faktor eksternal, juga berbicara mengenai peoples muggling tidak akan terlepas dari masalah imigran illegal atau imigran gelap. Kemudian adapun selain People Smuggling ada juga kejahatan transnasional hampir selalu berkaitan dengan kejahatan dengan motif finansial, yang membawa dampak terhadap kepentingan lebih dari satu negara. Kejahatan ini antara lain, , kejahatan terorganisir lintas batas negara (transborder organized criminal activity), pencucian uang (money laundering), kejahatan finansial (financial crimes), perusakan lingkungan secara disengaja (willful damage to the environment), dan lain-lain yang dapat mengakibatkan kestabilan politik di Indonesia tidak seimbang dan akan banyak berdampak buruk terhadap kehidupan sosial, budaya dan politik, akan ada banyak ketimpangan sosial akibat kejahatan Transnasional ini, maka Keimigrasian harus benar benar selektif dalam memeriksa orang asing yang ingin masuk ke wilayah Indonesia.

Pada tahun 2010, Conference of States Parties (CoSP) UNTOC yang kelima telah mengidentifikasi beberapa Kejahatan Lintas Negara Baru dan Berkembang (New and Emerging Crimes), antara lain cybercrime, identity-related crimes, perdagangan gelap benda cagar budaya, kejahatan lingkungan, pembajakan di atas laut, dan perdagangan gelap organ tubuh. Kejahatan Lintas Negara Baru telah menjadi perhatian dari dunia internasional mengingat jumlahnya yang semakin meningkat dan cara yang semakin beragam yang dapat mengancam keamanan negara. Kerugian yang ditimbulkan dari kejahatan jenis ini juga sangat besar. Kita lihat di Cina penegakan hukum terkait ekspansi warga negara tiongkok yang melakukan pelanggaran, mau tidak mau harus segera di laksanakan, terutama di bidang keimigrasian.Adapun beberapa bentuk kasus kejahatan internasional yang dapat mengancam keamanan, dan kedaulatan negara yang pernah terjadi di setiap negara termasuk Indonesia yaitu:

1. Perdagangan orang dan penyelundupan manusia, Isu perdagangan orang dan penyelundupan manusia dapat dikategorikan sebagai isu migrasi ireguler. Isu migrasi ireguler tersebut tetap menjadi isu sentral di dunia, yang selain menyangkut masalah perdagangan orang dan penyelundupan manusia, juga menyangkut isu pengungsi dan pencari suaka. Indonesia juga tidak luput mengalami peristiwa migrasi ireguler. Berdasarkan data UNHCR, pada tahun 2018 terdapat sekitar 14.000 pengungsi dan migran ireguler yang kebanyakan berasal dari Asia Tengah yang terdampar di Indonesia dalam upaya mencapai negara tujuan.

2. Kejahatan perdagangan dan penyelundupan Narkoba, Kejahatan penyalahgunaan narkotika dan obat terlarang (narkoba) pada umumnya bersifat lintas negara, mengingat produsen, kurir, dan korban bisa berasal dari negara yang berbeda-beda. Untuk itu, diperlukan diperlukan kerja sama internasional karena tidak dapat ditanggulangi oleh satu negara sendiri. Mengingat kondisi geografis dan demografis, Indonesia telah menjadi salah satu negara tujuan dari peredaran narkotika. Indonesia telah menempatkan kejahatan narkoba sebagai high-risk crime dan dalam penanganannya membutuhkan upaya yang luar biasa. Untuk itu Indonesia mendorong kerja sama internasional untuk meningkatkan 
upaya penanggulangan isu narkoba. Sekitar 1,4 juta di antaranya adalah pengguna biasa dan hampir 1 juta orang telah menjadi pecandu narkoba.

3. Kejahatan terhadap eksploitasi ilegal perikanan, Indonesia sebagai negara kepulauan memiliki kepentingan besar dalam menjaga wilayahnya dan menegakkan kedaulatan termasuk terhadap kejahatan perikanan.

Pada survey tahun 2017 yang dilakukan oleh Masyarakat Telekomunikasi, sekitar 91,8 persen berita sosial politik menyangkut Pilkada dan Pilpres yang ada di media sosial dikategorikan sebagai berita hoax Dikatakan bahwa kondisi tersebut sangatlah memprihatinkan karena akan berpengaruh terhadap kualitas peyelenggaraan Pemilu maupun hasil Pemilu itu sendiri, yang pada akhirnya akan merugikan masyarakat kejadian tersebut merupakan hal yang sangat krusial dimana berita yang tidak berdasarkan fakta di lapangan di sebarluaskan di jagad maya yang dapat merugikan banyak orang, ini dapat mengakibatkan ancaman kedaulatan negara yang berasal dari faktor Internal yang dapat memecah belahkan beberapa kelompok orang demi keuntungan tersendiri, Ancaman kedua adalah ancaman non-militer atau nirmiliter yang merupakan ancaman berdimensi ideologi, politik, ekonomi, sosial budaya, keselamatan, teknologi dan kesehatan umum, serta legislasi. Sedangkan ancaman ketiga adalah ancaman hibrida, yaitu ancaman yang memadukan ancaman militer dan ancaman non-militer. Ancaman hibrida dapat berupa gabungan ancaman konvensional, asimetrik, cyber warfare, dan war by proxy, maka untuk menghadapi ancaman tersebut, Djamaludin mengungkapkan bahwa diperlukan adanya peningkatan sinergitas TNI dan Polri dalam rangka mengamankan bangsa dan Negara sesuai dengan tugas, kewenangan dan tanggung jawab masing-masing.

Selain, dirinya juga mengatakan bahwa kesadaran masyarakat dalam bela Negara sangatlah penting sebagai upaya menghadapi ancaman-ancaman tersebut. Maka di sini senantiasa Keimigrasian juga bekerja sama dengan Jajaran lain seperti Menkopolhukam, TNI, POLRI dan sebagainya untuk senantiasa mengantisipasi siapa saja yang dapat mengancam keamanan, dan keselamatan negara juga menjaga tegaknya kedaulatan negara. Ada beberapa dampak serius yang ditimbulkan dari semakin meningkatnya keberadaan imigran ilegal di Indonesia. Dampak yang mungkin tidak dirasakan sekarang, tetapi beberapa tahun ke depan.Dampak secara ideologi. Keberadaan imigran ilegal (baca: pencari suaka dan pengungsi) di Indonesia, akan berdampak pada falsafah dan pandangan hidup negara Indonesia. Perbedaan latar belakang bangsa, bahasa, dan budaya tentu berpotensi merubah cara pandang dan kehidupan masyarakat (Syahrin, M. A. 2018)

\section{PERAN DAN PENGAWASAN KEIMIGRASIAN TERHADAP KEDAULATAN NEGARA}

Menurut Undang-Undang Nomor 6 Tahun 2011 tentang keimigrasian Penjelasan pasal 98 ayat (1) dan (2) yaitu Ayat(1)Kewenangan Penangkalan merupakan wujud dari pelaksanaan kedaulatan negara untuk menjaga keamanan dan ketertiban umum yang dilaksanakan berdasarkan alasan Keimigrasian. Ayat(2) Pejabat yang berwenang dalam ketentuan ini adalah pimpinan instansi pemerintah. Adapun Upaya keimigrasian terhadap Penegakan Hukum terhadap Tindak Pidana Keimigrasian Yaitu:

1. Pengawasan Keimigrasian,Pengawasan keimigrasian tidak hanya pada saat mereka masuk dan keluar dari wilayah Indonesia, tetapi juga selama mereka berada di wilayah Indonesia termasuk kegiatan-kegiatannya. Pengawasan adalah suatu kegiatan yang menentukan apa yang sedang diselenggarakan yakni mengevaluasi penyelenggaraan dan bilamana perlu mengambil tindakan 
korektif sehingga penyelenggaraan itu berlangsung dengan rencana.Dengan adanya kegiatan pengawasan.kementrian Hukum dan HAM diberi wewenang khusus yang tidak dimiliki oleh instansi lain untuk mengambil tindakan tertentu sebagai suatu tindakan administartif imigrasi terhadap orang asing.Menurut pasal 69 UU Nomor 6 Tahun 2011 tentang keimigrasian adalah "Untuk melakukan pengawasan Keimigrasian terhadap kegiatan Orang Asing di Wilayah Indonesia, Menteri membentuk tim pengawasan Orang Asing yang anggotanya terdiri atas badan atau instansi pemerintah terkait, baik di pusat maupun di daerah.

2. Tindakan Keimigrasian, Tindakan keimigrasian ini dilakukan sebagai pelaksanaan kebijaksanaan pengawasan di bidang keimigrasian terhadap orang asing yang berada di wilayah Republik Indonesia yang melakukan kegiatankegiatan yang bertentangan dengan peraturan perudang-undangan yang berlaku.keimigrasian diluar tindakan hukum pidana atau penyidikan masuk kategori Tindakan Keimigrasian. Selain menurut ketentuan hukum positif tersebut diatas, juga menurut hukum internasional bahwa tindakan keimigrasian berupa deportasi bukan tindakan hukum pidana dan ini berlaku secara universal pada negara-negara lain di dunia(Bambang Hartono).daftar Pencegahan atau Penangkalan; b. pembatasan,perubahan, atau pembatalan Izin Tinggal; c. larangan untuk berada di satu atau beberapa tempat tertentu di Wilayah Indonesia; d. keharusan untuk bertempat tinggal di suatu tempat tertentu di Wilayah Indonesia; e. pengenaan biaya beban; dan/atau f. Deportasi dari Wilayah Indonesia. (3) Tindakan Administratif Keimigrasian berupa Deportasi dapat juga dilakukan terhadap Orang Asing yang berada di Wilayah Indonesia karena berusaha menghindarkan diri dari ancaman dan pelaksanaan hukuman di negara.

3. Karantina Imigrasi, Karantina imigrasi adalah tempat penampungan sementara bagi orang asing yang dikenakan proses pengusiran atau deportasi atau tindakan keimigrasian lainnya. Namun karantina imigrasi diganti dengan Rumah Detensi Imigrasi berdasarkan Peraturan Menteri Hukum dan Hak Asasi Manusia Republik Indonesia Nomor M.05IL.02.01 Tahun 2006 tentang Rumah Detensi Imigrasi (Bambang Hartono)

Luas lingkup keimigrasian tidak lagi hanya mencakup pengaturan, penyelenggaraan keluar masuk orang dari dan kedalam wilayah Indonesia, serta pengawasan orang asing yang berada di wilayah Indonesia, tetapi telah bertalian juga dengan pencegahan orang keluar dari wilayah Indonesia dan penangkalan orang masuk ke wilayah Indonesia demi kepentingan umum, penyidikan atas dugaan terjadinya tindak pidana keimigrasian, ini juga berdampak penting terhadap kestabilan politik dan ekonomi, serta keamanan dan pertahanan negara dan berdampak baik terhadap kedaulatan negara, serta pengaturan prosedur keimigrasian dan mekanisme pemberian izin keimigrasian, maka, dapat dikatakan bahwa fungsi keimigrasian merupakan fungsi penyelenggaraan administrasi negara atau penyelenggaraan administrasi pemerintahan (Imam Santoso. 2018) Permasalahan kedaulatan negara jugae adanya keberadaan pencari suaka dan pengungsi di Indonesia yang tidak dapat dipisahkan dari intervensi lembaga internasional dengan manjadikan hak asasi manusia sebagai dasar pembenarannya. Prinsip yang terkenal dalam hukum pengungsi adalah prinsip larangan pengusiran bagi pengungsi dan pencari suaka ke negara asalnya (non- refoulement) yang diatur dalam Pasal 33 Ayat (1) Konvensi Tahun 1951 tentang Status Pengungsi(Syahrin, M. A. 2018) Melihat fungsi dan perannya batas imajiner memiliki 
arti penting sebagai penanda kedaulatan negara, bukan sebagai batas antrian saja. Selective policy suatu negara terhadap orangorang yang akan masuk juga terlaksana di batas ini, inilah yang dikenal sebagai wujud dari hak eksklusif negara yang berdaulat (Fahroy, C. A. 2017). Disini bisa dilihat data Tindak pidana terhadap WNA yang mengancam kedaulatan negara

Tabel.3. Data Pelaku WNA Berdasarkan Tindak Pidana Tahun 2015 -2016

\begin{tabular}{llll}
\hline No & Kasus Kejahatan & 2015 & 2016 \\
\hline 1 & Legalitas Dokumen & 271 & 91 \\
\hline 2 & Pembunuhan & 37 & 19 \\
3 & $\begin{array}{l}\text { Penipuan Online / Cyber } \\
\text { Crime }\end{array}$ & 189 & 82 \\
4 & Perdagangan Manusia & 91 & 19 \\
5 & Penganiaan & 4 & 13 \\
\hline 6 & Pencurian & 7 & 3 \\
7 & Narkoba & 28 & 27 \\
\hline 8 & Terorisme & - & 2 \\
9 & Lain-Lain & 88 & 7 \\
\hline
\end{tabular}

Peran Direktorat Jenderal Imigrasi (Kemenkumham) dalam memerangi (combat) Kejahatan Internasional yang menggangu ketertiban masyarakat, sangat besar dan strategis, hal ini dikaitkan dengan tugas dan fungsinya sebagai penjaga pintu gerbang wilayah Indonesia, terhadap arus lalu lintas masuknya orang asing ke Indonesia, imigrasi menerapkan kebijakan yang selektif (selective policy) bagi orang asing yaitu hanya orang asing yang memberi manfaat dan tidak mengganggu keamanan dan ketertiban yang diperbolehkan memasuki wilayah Indonesia.Dalam jenis tindak pidana yang bersifat Internasional salah satunya adalah Terorisme, terorisme bisa berdampak buruk terhadap keamanan dan ketahanan suatu negara baik faktor nya berasal dari dalam maupun dari luar. Di dalam intelijen keimigrasian, terorisme dikenal juga yaitu Pergerakan Foreign Terrorist Fighters (FTF), Foreign Terrorist Fighters adalah para pejuang teroris asing yang merupakan individu yang melakukan perjalanan ke negara lain untuk tujuan perbuatan, perencanaan, atau persiapan, atau partisipasi dalam, tindakan teroris atau penyediaan atau penerimaan pelatihan teroris, termasuk konflik"Foreign terrorist fighters are "individuals who travel to a State other than their States of residence or nationality for the purpose of the perpetration, planning, or preparation of, or participation in, terrorist acts or the providing or receiving of terrorist training, including in connection with armed conflict" (Trisapto Wahyudi Agung Nugroho). Kemudian peran Imigrasi terhadap kedaulatan negara terdapat pada pemeriksaan Tempat Pemeriksaan Keimigrasian, Pemeriksaan di TPI dilakukan untuk mengatahui validitas dan perekaman dokumen perjalanan dalam data perlintasan yang digunakan si pemegang, yang kemudian diikuti dengan peneraan cap kemigrasian berupa tanda masuk atau keluar (Fahroy, C. A. 2017).

Adapun beberapa poin penting terhadap pemeriksaan keimigrasian dalam menjaga kedaulatan negara yaitu:

a. Sebagai kedaulatan negara, cap ini diterakan di dokumen perjalanan merupakan simbol kekuasaan negara yang berdaulat, dimana negara menjalankan hak eksklusifnya untuk menyaring orang yang akan masuk atau keluar wilayahnya;

b. Pembatasan wewenang suatu hukum negara dari si pemegang atau pemilik dokumen perjalanan terhadap aturan hukum yang berlaku dalam sebuah negara;

c. Bukti otentik seseorang berada dalam suatu wilayah negara tertentu yang sah secara dan dapat dipertanggung jawabkan secara yuridis;

d. Tanda yang digunakan untuk melanjutkan proses izin tinggal bagi warga negara asing (WNA) yang akan menetap, melaksanakan kegiatan tertentu di suatu wilayah negara.

Kedaulatan negara terbagi ke dalam dua bentuk yaitu kedaulatan yang berasal dari 
dalam dan kedaulatan dari luar yang dimana jika kedaulatan negara yang berasal dari dalam maka negara dan pemerintahannya wajib mengatur segala kepentingan rakyatnya. Sejak berdirinya organisasi internasional PBB, perlu dikemukakan beberapa hal penting berkaitan dengan caracara tradisional dalam hal perolehan kedaulatan teritorial oleh negara sebagai berikut:

1 Pertama, hukum internasional modern terutama sejak berdirinya $\mathrm{PBB}$, telah melarang penggunaan kekerasan dalam hubungan internasional sebagaimana ditegaskan dalam Piagam PBB. Perolehan kedaulatan atas suatu wilayah tertentu melalui penaklukan dengan cara kekerasan merupakan cara yang tidak dapat dibenarkan dan ilegal. Perolehan kedaulatan atas suatu wilayah tertentu yang terjadi sebelum berdirinya PBB ditetapkan berdasarkan hukum antar waktu (intert-temporallaw).

2 Kedua, perolehan dan penerapan kedaulatan oleh suatu negara terhadap suatu wilayah tertentu diatur oleh dan didasarkan pada hak untuk menentukan nasib sendiri (rightof self-determination).

3 Ketiga, dalam kerangka hukum internasional kontemporer, penggunaan caracara kekerasan dalam hubungan internasional tidak dapat dibenarkan ; kecuali, dalam halhal tertentu yang didasari oleh alasan-alasan kuat dan sah menurut hukum internasional (Riyanto, S. 2012).

Keimigrasian terus melakukakan kontribusi terhadap kebijakan dan penegakan hukum terhadap pengawasan orang asing dan pengawasan izin tinggal terhadap orang asing. Secara teoritik terdapat dua landasan yang berbeda yang perlu dikemukakan yang masing masing mendasari kedaulatan negara(sovereignty) dan hak menentukan nasib sendiri (self determination). Landasan teoritik tersebut dikenal dengan istilah atau pendekatan"sovereignty first" dan "selfdetermination first". Pendekatan yang mengutamakan kedaulatan ("sovereignty first"), terutama dilandasi oleh prinsip kedaulatan negara (sovereignty), integritas teritorial (territorial integrity) dan kemerdekaan politik (political independence) (Riyanto, S. 2012)

\section{PENUTUP \\ Kesimpulan}

Dengan adanya perkembangan globalisasi dan ekonomi yang kian meningkat dan jumlah peningkatan penduduk yang kian bertambah membuat manusia bermigrasi ke negara- negara lain. Dengan adanya dampak perubahan siklus perekonomian di setiap negara berbeda beda serta mobilitas sosial dan diferensiasi sosial juga ketimpangan sosial maka akan timbul kriminalitas di setiap negara. Dengan adanya hal tersebut, maka keimigrasian harus selektif dalam menerima orang asing (foreign) ke Indonesia, guna menjaga stabilitas keamanan negara dari ancaman, gangguan, dan hambatan dari luar. Faktor ancaman kedaulatan negara bukan hanya saja berasal dari luar yang mana ancaman itu berupa ideologi baru yang dapat memecah kedaulatan negara, Terorisme, Traffiking, dan Smuggling. Imigrasi berfungsi sebagai penjaga pintu gerbang negara, dapat dikatakan demikian karena imigrasi merupakan institusi pertama dan terakhir yang menyaring kedatangannya dan keberangkatan orang asing ke dan dari wilayah Republik Indonesia.

Pelaksanaan fungsi keamanan yang ditujukan kepada Warga Negara Indonesia dijabarkan melalui tindakan pencegahan ke luar negeri bagi Warga Negara Indonesia atas permintaan Menteri Keuangan dan Kejaksaan Agung tindakan ini guna untuk menghindari adanya ancaman dan gangguan yang dapat menyebabkan hilangnya kotrol kedaulatan negara khusus Warga Negara Indonesia (WNI) tidak dapat dilakukan pencegahan karena alasan-alasan keimigrasian belaka. Dalam sejarah antar bangsa, dan praktik kenegaraan, keterkaitan 
antara kedaulatan(sovereignty) dan hak menentukan nasib sendiri. Adapun beberapa bentuk kasus kejahatan internasional yang dapat mengancam keamanan, dan kedaulatan negara yang pernah terjadi di setiap negara termasuk Indonesia yaitu:

1. Perdagangan orang dan penyelundupan manusia, Isu perdagangan orang dan penyelundupan manusia dapat dikategorikan sebagai isu migrasi ireguler.

2. Kejahatan perdagangan dan penyelundupan Narkoba, Kejahatan penyalahgunaan narkotika dan obat terlarang (narkoba) pada umumnya bersifat lintas negara, mengingat produsen, kurir, dan korban bisa berasal dari negara yang berbeda-beda.

3. Kejahatan terhadap eksploitasi ilegal perikanan

Menurut ahli Mueller kejahatan Transnasional atau yang disebut juga kejahatan Internasional yang dapat mengancam kedaulatan negara yaitu."Kejahatan transnasional adalah istilah yuridis mengenai ilmu tentang kejahatan, yang diciptakan oleh perserikatan bangsabangsa bidang pencegahan kejahatan dan peradilan pidana dalam hal mengidentifikasikan fenomena pidana tertentu yang melampaui perbatasan internasional, melanggar hukum dari beberapa negara, atau memiliki dampak pada negara lain. dan Bassiouni mengatakan bahwa kejahatan transnasional atau transnational crime adalah kejahatan yang mempunyai dampak lebih dari satu negara, kejahatan yang melibatkan atau memberikan dampak terhadap warga negara lebih dari satu negara, sarana dan prasarana serta metodametoda yang dipergunakan melampaui batasbatas teritorial suatu negara.

Jadi istilah kejahatan transnasional dimaksudkan untuk menunjukkan adanya kejahatan-kejahatan yang sebenarnya nasional (di dalam batas wilayah negara), tetapi dalam beberapa hal terkait kepentingan negara-negara lain. Dengan menghadapi adanya kejahatan Transnasional maka Keimigrasian melakukan upaya- upaya hukum untuk menjaga stabilitas keamanan dan ketahanan negara yaitu dengan adanya pengawasan keimigrasian Pengawasan Keimigrasian. Pengawasan keimigrasian tidak hanya pada saat mereka masuk dan keluar dari wilayah Indonesia, tetapi juga selama mereka berada di wilayah Indonesia termasuk kegiatan-kegiatannya. Pengawasan adalah suatu kegiatan yang menentukan apa yang sedang diselenggarakan yakni mengevaluasi penyelenggaraan dan bilamana perlu mengambil tindakan korektif sehingga penyelenggaraan itu berlangsung dengan rencana. Kemudian upaya hukum selanjutnya adalah Tindakan Keimigrasian. Tindakan keimigrasian ini dilakukan sebagai pelaksanaan kebijaksanaan pengawasan di bidang keimigrasian ter-hadap orang asing yang berada di wilayah Republik Indonesia yang melakukan kegiatan-kegiatan yang bertentangan dengan peraturan perudangundangan yang berlaku. Dan upaya hukum selanjutnya adalah Pencegahan dan Penangkalan. Pelaksanaan pencegahan dan penangkalan adalah wewenang Kementerian hukum dan HAM yang dikeluarkan melalui Direktorat Jenderal Imigrasi. tersebut dapat berpengaruh/ mengancam stabilitas negara. Adapun Upaya keimigrasian serta peran keimigrasian dalam menghadapi ancaman kedaulatan negara serta Penegakan Hukum terhadap Tindak Pidana Keimigrasian yang akan mengancam keamanan negara yaitu:

1. Pengawasan Keimigrasian, Pengawasan keimigrasian tidak hanya pada saat mereka masuk dan keluar dari wilayah Indonesia, tetapi juga selama mereka berada di wilayah Indonesia termasuk kegiatan-kegiatannya. Dengan adanya kegiatan pengawasan.kementrian Hukum dan HAM diberi wewenang khusus yang tidak dimiliki oleh instansi lain untuk mengambil tindakan tertentu sebagai suatu tindakan administartif imigrasi terhadap orang asing. 
2. Tindakan Keimigrasian, Tindakan keimigrasian ini dilakukan sebagai pelaksanaan kebijaksanaan pengawasan di bidang keimigrasian terhadap orang asing yang berada di wilayah Republik Indonesia yang melakukan kegiatankegiatan yang bertentangan dengan peraturan perudang-undangan yang berlaku.

3. Karantina Imigrasi, Karantina imigrasi adalah tempat penampungan sementara bagi orang asing yang dikenakan proses pengusiran atau deportasi atau tindakan keimigrasian lainnya (Trisapto Wahyudi Agung Nugroho)

\section{Saran}

1. Perlu adanya pemahaman tentang kedaulatan negara dan apa saja ancaman yang dapat menggangu ketertiban dan kedaulatan negara, dengan menjalankan keamanan kedaulatan negara maka pengawasan dan intelijen negara terhadap keberadaan dan kegiatan orang asing di Indonesia perlu di lakukan dengan cara tukar menukar informasi dengan komunitas intelijen pusat maupun di daerah. Kemudian data tersebut diverifikasi dan dianalisis sehingga dapat diambil suatu tindakan (contoh: Pihak Direktorat Intelijen Imigrasi memberikan data visa orang asing kepada Direktorat Intelijen Perpajakan yang kemudian data tersebut dapat digunakan untuk menelusuri 'kejahatan" perpajakan yang dilakukan oleh orang asing tersebut) sehingga kejahatan dapat di antisipasi dan dapat menganalisis seberapa besar persentase kejahatan Transnasional tersebut.

2. Perlu Sumber Daya Manusia dengan cara melakukan pendidikan dan pelatihan terkait analisis intelijen data dan intelijen keimigrasian, pengawasan keimigrasian dan pencegahan dan penagkalan terhadap orang asing maupun operasi intelijen, , pengamanan dan pengawasan keberadaan orang asing, serta perlu adanya sistem informasi keimigrasian yang mumpuni dalam menjaga keamanan negara

3. Setiap penyelenggara pengawasan keimigrasian,dan intelijen keimigrasian harus diberikan hak akses untuk menerima dan memberikan informasi

4. Pihak dari keimigrasian saling bekerjasama dengan lembaga negara lain agar penegakan hukum serta kestabilan politik dan ekonomi semakin baik. Dan untuk saling tukar informasi orang asing untuk keamanan, dan pertahanan negara.

\section{DAFTAR PUSTAKA}

\section{Buku}

Imam Santoso, Santoso, M. I., \& Imam Santoso. (2018). KEDAULATAN DAN YURISDIKSI NEGARA DALAM SUDUT PANDANG KEIMIGRASIAN. Binamulia Hukum.

\section{Jurnal Ilmiah}

Agung Nugroho, Trisapto Wahyudi, " Peran Intelijen Keimigrasian Dalam Rangka Antisipasi Terhadap Potensi Kerawanan Yang Ditimbulkan Oleh Orang Asing Di Wilayah Indonesia " Jurnal Penelitian Hukum, Oktober 2018: 275-293.

http://dx.doi.org/10.30641/kebijakan.2018.V $\underline{12.275-293.275-293}$

Hartono, Bambang, "Upaya Penegakan Hukum terhadap Tindak Pidana Keimigrasian" Jurnal Penelitian Hukum 4.

http://jurnal.ubl.ac.id/index.php/KP/article/d ownload/69/66

Fahroy, C. A. (2017). ASPEK HUKUM INTERNASIONAL PADA BATAS“IMAJINER” NEGARA. Jurnal Wawasan Yuridika. https://doi.org/10.25072/jwy.v1i1.12 $\underline{7}$ 
Jurnal Sains Riset (JSR)

p-ISSN 2088-0952, e-ISSN 2714-531X

http://journal.unigha.ac.id/index.php/JSR

DOI. $10.47647 /$ jsr.v10i12

Syahrin, M Alvi. (2016). Eksodus Warga Negara Tiongkok: Antara Kebijakan dan Penyelundupan. Checkpoint, 2931.

Syahrin, M Alvi. (2018). Jus Cogens dalam Protokol Penyelundupan Migran Tahun 2000. Bhumi Pura, 2(1), 1316.

Syahrin, M Alvi. (2019). Kepastian Hukum dan Kekuatan Bangsa. Petak Norma, $4(2), 1-4$.

Syahrin, M Alvi. (2014). Penyadapan oleh Australia, Saatnya Imigrasi Bersikap. Bhumi Pura, 1(1), 30-35.

Riyanto, S. (2012). KEDAULATAN NEGARA DALAM KERANGKA HUKUM INTERNASIONAL KONTEMPORER. Yustisia Jurnal Hukum.

https://doi.org/10.20961/yustisia.v1i 3.10074

Syahrin, M. A. (2018). Menakar Kedaulatan Negara dalam Perspektif Keimigrasian. Jurnal Penelitian Hukum De Jure.https://doi.org/10.30641/dejure. 2018.v18.43-57

\section{Peraturan Perundang- undangan}

Indonesia, Undang-Undang tentang Keimigrasian, UU No. 6 Tahun 2011, LN Tahun 2011 Nomor 52.

Internet

"Kejahatan Narkoba Sebagai Fenomena Dari Transnasional Organized Crime Di Indonesia", dalam https://krisnaptik.com/2013/03/03/ke jahatan-narkoba-sebagai-fenomenadari-transnational-organized-crime- di-indonesia/ , diakses pada hari Selasa(22/03/2021), pukul 17.48 WIB.

"Kejahatan lintas negara", dalam www.kemlu.go.id/Pages/lissueDispla y.aspx ?IDP=20\&l=id, diakses pada hariSelasa(22/03/2021), pukul 17.48 WIB.

" Pengertian Kejahatan Transnasional https://pengertianmenurutahli.blogsp ot.com/2013/11/pengertian-

kejahatan-transnasional.htmldiakses pada hariSelasa(22/03/2021), pukul 17.48 WIB..

\section{"TENTANG TINDAK PIDANA} KEIMIGRASIAN"

http://asakeadilan.blogspot.com/2014/04/ten tang-tindak-pidana-

keimigrasian.html, diakses pada hari Selasa(22/03/2021), pukul 17.48 WIB.

"TEORI KEBIJAKAN SELEKTIF KEIMIGRASIAN"http://muhammad alvisyahrin.blogspot.com/2018/09/te ori-kebijakan-selektifkeimigrasian.html, diakses pada hari Selasa(22/03/2021), pukul 17.48 WIB.

"Apa yang dimaksud dengan kedaulatan negara?"https://www.dictio.id/t/apayang-dimaksud-dengan-kedaulatannegara/9286 di akses padaSelasa(22/03/2021), pukul 17.48 WIB.

http://alfonsiusjojosiringoringo.blogspot.co $\mathrm{m} / 2012 / 12 /$ transnasional-crime.html, diakses pada hari Selasa(22/03/2021), pukul 17.49 WIB.

"Kejahatan Lintas Negara"http://www.kemlu.go.id/id/k 
Jurnal Sains Riset (JSR)

p-ISSN 2088-0952, e-ISSN 2714-531X

http://journal.unigha.ac.id/index.php/JSR

DOI. 10.47647/jsr.v10i12

ebijakan/isukhusus/pages/Penanggul anganKejahatanLintasNegara-

Terorganisir.aspx, diakses pada

Selasa(22/03/2021), pukul 17.50WIB.

"Kejahatan

Lintas

Negara"https://kemlu.go.id/portal/id/

"Laporan Tahunan Perdagangan Orang 2018"https://id.usembassy.gov/id/our relationship-id/official-reportsid/laporan tahunan-perdaganganorang-2018/ diakses pada hari Selasa(22/03/2021), pukul 17.48 WIB. read/89/halaman_list_lainnya/kejahat an-lintas-negara diaksesSelasa(22/03/2021), pukul 17.48 WIB. 